\title{
$>$ Sobre o conceito de consciência em Heidegger
}

\author{
> About the notion of conscience in Heidegger
}

\section{por Fabíola Menezes Araújo}

Doutora em Teoria Psicanalítica (UFRJ) e Doutoranda em Filosofia Antiga (PUC-RJ). Email: confabulando@gmail.comORCID: 0000-0002-8295-2536

\section{por Rafael Ribeiro Almeida}

Graduando em Filosofia na Universidade Estadual de Santa Cruz (UESC, Ilhéus, BA). Email: estudosrafael@gmail.com. ORCID: 0000-0002-5040-878X

\section{Resumo}

Pretendemos examinar a noção de consciência (Gewissen) na primeira fase do pensamento heideggeriano. Para tanto, investigamos Ser e Tempo, em especial o segundo capítulo da segunda seção (\$§ 55-60), no qual o autor destaca o fenômeno da consciência como existencial e originário, designando-o como apelação. Através da consciência - ao apelar e ao mesmo tempo compreender o clamor dessa apelação - o seraí, enquanto ser-no-mundo, pode ser de modo autêntico. Notemos que à pergunta quem clama nessa aclamação, responde-se: o ser-aí angustiado. A consciência, dessa forma, designa o movimento pelo qual o ser-aí direciona-se para o seu poder-ser, em sentido autêntico que, como possibilidade, já e sempre é.

Palavras-chave: Consciência. Ser e Tempo. Apelação. Autenticidade.

\begin{abstract}
We intend to examine the notion of conscience (Gewissen) in Heidegger's first phase's thought. For that, we consider Being and Time, especially the second chapter's second section (\$§ 55-60), in which the author emphasizes the phenomenon of conscience as existential and originary, designating it as appealing. Through conscience - by appellation and at the same time by understanding the appeal of that appellation - the Dasein, as being-in-the-world, can be authentic. It is noticed that to the question of who claims in that appellation, the answer is: the distressed Dasein. Conscience, thus, designates the movement by which the Dasein addresses itself for its can-be, that he already and always is.
\end{abstract}

Keywords: Conscience. Being and Time. Appellation. Authenticity. 


\section{Considerações introdutórias}

É de notório conhecimento que o tratado de Ser e Tempo consiste na elaboração e explicitação da questão do sentido do ser. De início podemos afirmar que esta questão se mostra possível a partir do ente que é simultaneamente tema e a questão em vista da qual a questão pôde ser colocada, a saber, o Dasein: quem é este ser que pode perguntar pelo sentido do ser? Ledo engano, no entanto, considerar que o termo Dasein designe o conceito heideggeriano de homem. Na verdade, o termo em questão inviabiliza, por excelência, a própria colocação da pergunta o que é o homem?. É na medida em que o Dasein designa um modo de ser radicalmente distinto de todos os entes caracterizados por propriedades quididativas e determinações essenciais que esta pergunta se mostra inviabilizada. Em si e por si mesmo, ser-aí não possui uma razão, um corpo, uma alma ou qualquer outra faculdade na condição de apanágio: do ponto de vista de uma condição mais originária, o ser-aí sequer tem vida.

O leitor familiarizado com a economia interna de Ser e Tempo dificilmente não se sentirá surpreso ou ao menos intrigado com a aparição do conceito de consciência, e com a perspectiva deste conceito ser designado com veemência, nesta obra, como fenômeno originário do ser-aí. Posto nestes termos, gostaríamos de trazer à tona a reconstrução temática realizada por Heidegger, em Ser e Tempo, no tocante ao seu conceito de consciência, e, além disso, interpelar determinadas questões e certos impasses em torno desse conceito. Se, por um lado, os 83 parágrafos do tratado incompleto publicado em 1927 lançam bases para a superação das (tradicionais) teorias da consciência e da representação fundadas na relação sujeito-objeto, por outro lado, em que medida Heidegger, ao 
trazer à tona a noção de consciência (Gewissen) em Ser e Tempo, não se coadunaria com as mesmas teorias que critica? Em outras palavras: por que e em que medida o filósofo que problematiza e recusa as noções de subjetividade, de razão inata, de intuição e de introspecção como critérios para a análise do fenômeno da existência, e que termina por recusar até mesmo as posições que privilegiam a consciência como ponto de partida, termina não só por admitir a consciência, mas também por afirmá-la como um existencial fundamental do Dasein, vulgo Ser-aí?

Eis os problemas de que tratamos neste artigo: o que Heidegger teria em vista com a afirmação de que o Dasein é ou tem consciência? O que diferencia a obra Ser e Tempo no tocante à definição deste termo da tradição filosófica de onde ela provém? Como a analítica existencial articula o fenômeno da consciência? Por fim, restará pensarmos se a consciência, tal como afirmada em Ser e Tempo, deve ser tomada como um existencial, ou seja, como um fenômeno a priori, a exemplo do fenômeno da compreensão $\left(\right.$ Verstehen $\left.^{1}\right)$, ou não, isto é, se trataria de um fenômeno meramente histórico que, nesta medida, poderia advir ou não. Por último, verifica-se aqui a necessidade de um breve adendo acerca da edição da obra Ser e tempo por nós utilizada. ${ }^{2}$

${ }^{1} \mathrm{O}$ termo Verstehen, designado pelo prefixo Ver (pré, antes) e pelo verbo Stehen, significa etimologicamente permanecer antes, como veremos adiante este termo se distingue do termo Bewusstein, também traduzido por consciência. Etimologicamente o termo Bewusstsein deriva-se do particípio passado do verbo ser (Sein), remetendo-nos ao sentido de tendo sido.

${ }^{2}$ Assim como outros clássicos da história da Filosofia, a obra de Ser e Tempo é sabidamente intraduzível de maneira plena e definitiva para o português, quer por se tratar da polissemia da língua alemã, quer pela inexistência de palavras em português capazes de corresponder ao termo no original, ou mesmo devido ao aspecto idiossincrático dos termos heideggerianos. Nesse sentido, seja qual for a preferência em relação às edições brasileiras disponíveis, comportará a versão escolhida controvérsias no que diz respeito à precisão terminológica, restando-nos a tarefa de evidenciar a composição do conceito em busca de seu sentido originário. Por exemplo, em relação à edição brasileira de Ser e Tempo, traduzida pela Márcia de Sá, não são raros os estudiosos 


\section{Sobre a acepção heideggeriana de consciência}

Convém, inicialmente, retomarmos certas indagações aludidas acima: de que modo Heidegger aborda a consciência [Gewissen ${ }^{3}$ ] e como este conceito vem à tona em Ser e Tempo? Martin Heidegger - "pensador da mais vasta obra filosófica do século XX, em torno de 102 volumes" $^{4}$ - não se notabilizou na história do pensamento ocidental por tematizar um projeto filosófico especializado no tocante à consciência, "possivelmente a fonte de problemas mais penetrante e provocante de toda a filosofia"5; aliás, como observa o pesquisador Ronaldo Manzi, no artigo $O$ que seria a consciência na fenomenologia heideggeriana?, Heidegger sequer realizou uma filosofia da consciência e tampouco conferiu um lugar privilegiado ao fenômeno em questão: “Obviamente que encontramos um papel para a consciência em Heidegger, mas o fato dela figurar em sua ontologia não nos dá o ‘direito' de sugerir que ele está realizando uma

que afirmam que "mesmo possuindo reedições, ainda ficam (as traduções) aquém das expectativas do público estudioso" (Roberto Mertens-Kahlmeyer, "Resenha: Heidegger, Martin. Ser e tempo. Trad. de Fausto Castilho. Editora da Unicamp; Vozes, 2012", 2013, p. 103). Por outro lado, mesmo a recente edição traduzida por Fausto Castilho (bilíngue), frequentemente elogiada pelo "discurso consideravelmente mais fluido, com fraseologia direta e isenta das afetações estilísticas" (Idem), comporta, de uma forma ou de outra, algumas imprecisões em termos de vocabulário heideggeriano, haja vista a opção de Castilho por traduzir a palavra alemã Verstehen por "entendimento" (ao tentar aproximar tal vocábulo alemão do latino intellegere), termo tão crucial para o pensamento heideggeriano de modo geral (ou outros termos menos centrais, como a tradução de Umwelt por “mundo-ambiente, e Bewandtnis por conjuntação). Em vista disso, tornase extremamente difícil o consenso quanto ao uso de apenas uma tradução no caso da clássica obra de Ser e Tempo. Mediante isso, embora privilegiemos a edição traduzida por Márcia de Sá no presente artigo, também utilizaremos o recurso de comparação, quando necessário, entre as traduções, como é o caso da também prestigiada edição espanhola de Ser y Tiempo, traduzida por Jorge Eduardo Rivera.

${ }^{3}$ Trata-se de Gewissen, substantivo derivado do verbo wissen, saber, que com o prefixo Ge significa tendo sabido. Tanto Bewusstsein quanto Gewissen são traduzidos por consciência.

${ }^{4}$ Rüdiger Safranski, Heidegger - um mestre da Alemanha entre o bem e o mal, 2000, p. 13.

${ }^{5}$ Simon Blackburn, Dicionário Oxford de filosofia, 1997, p. 72, Grifo nosso. 
filosofia da consciência"6. E mais. Simon Critchley e Reiner Scürmann (no texto On Heidegger's Being and Time), chamam-nos a atenção: “A discussão da consciência é uma das mais explosivas e interessantes partes de Ser e Tempo"7. Como se vê, portanto, vários são os comentadores de Heidegger que destacam a relevância da noção de Gewissen para o pensador, tais como Ernst Tugendhat, no texto Selbstbewusstsein und Selbstbestimmung [Auto-consciência e autodeterminação] ${ }^{8}$, e Chen Yong, em Bewusstsein und Erschlossenheit Untersuchung zu Descartes und Heidegger [Consciência e abertura - estudo sobre Descartes e Heidegger $]^{9}$. Mas, afinal, o que Martin Heidegger, na primeira fase do seu pensamento, entende por consciência? Em que sentido os 83 parágrafos de Ser e Tempo não só trazem à liça o conceito de consciência, como a concebe de maneira originária, e por isso nova, diferenciando-se deste modo da metafísica moderna?

As respostas às perguntas acima não precisam ser conjecturadas, mas engendradas a partir do modo como o próprio autor aborda o conceito de consciência na segunda seção do segundo capítulo do tratado de Ser e Tempo. É preciso evitar, preliminarmente, uma imprecisão conceitual e terminológica sobre o sentido que Heidegger tem em vista quando ele se refere à palavra Gewissen, em português consciência. De acordo com o Dicionário de Filosofia, de autoria de Ferrater Mora:

\footnotetext{
${ }^{6}$ Ronaldo Manzi, “O que seria a consciência na fenomenologia heideggeriana?", 2016, p. 196.

7 "the discussion of conscience is one of the most explosive and interesting parts of Sein und Zeit". Simon Critchley e Reiner Scürmann, On Heidegger's Being and Time, 2008, p. 145. Tradução nossa.

${ }^{8}$ Ernst Tugendhat, Selbstbewusstsein und Selbstbestimmung: Sprachanalytische Interpretationen, 1981.

${ }^{9}$ Chen Yong, Bewusstsein und Erschlossenheit - Untersuchung zu Descartes und Heidegger, 2013.
} 
O termo 'consciência' tem pelo menos dois sentidos: 1) consideração ou reconhecimento de algo, seja de algo exterior, como um objeto, uma qualidade, uma situação etc., ou de algo interior, como as modificações experimentadas pelo próprio eu; 2) conhecimento do bem e do mal. $O$ sentido 2) é expresso mais propriamente por meio da expressão 'consciência moral'. [...] Em alguns idiomas, empregam-se termos diferentes para os dois sentidos mencionados: por exemplo, Bewußtsein, Gewissen (em alemão), consciousness, conscience (inglês), respectivamente ${ }^{10}$.

Em consonância com a citação (acima), nota-se que o idioma alemão diferencia terminologicamente Bewußtsein, enquanto reflexão de um eu sobre si mesmo, ou seja, consciência psicológica, e Gewissen cujo sentido é ter conhecimento (moral) do bem e do mal. É verdade que tanto Gewissen (consciência moral), quanto Bewußtsein (consciência) têm, ambas as palavras, origem no termo Wissen (saber), no caso específico de Gewissen, no entanto, há uma valoração moral implicado nesse saber, uma valoração moral sobre a qual se fala de voz da consciência.

Em Ser e Tempo Heidegger recusa veementemente a noção de Bewußtsein. Por isso que a investigação de Heidegger evita vias interpretativas que reconduzam à definição de "consciência a uma das faculdades da alma, entendimento, vontade ou sentimento, ou a explica como uma mistura desses elementos"11, justamente o que indica a noção de Bewußtsein. O filósofo alemão, valendo-se do termo Gewissen, quer superar a metafísica que se depreende do termo Bewußtsein. Nesse sentido, urge destacarmos uma parte do sumário original de Sein und Zeit, a partir dos \$§ 55-60, no qual Heidegger, através de sua analítica existencial, se debruça sobre o problema da consciência: “\$55 Os

\footnotetext{
${ }^{10}$ Ferrater Mora, Dicionário de Filosofia - tomo I a IV, 2000, p. 550, grifo nosso.

${ }^{11}$ Martin Heidegger, Ser e Tempo - parte II, 2005a, p. 57.
} 
fundamentos existencial-ontológicos da consciência/ §56 O caráter de chamado da consciência/ \$57 A consciência como uma chamada de preocupação ou cuidado"12.

Heidegger vale-se do termo Gewissen e interpreta-o sob uma nova perspectiva, qual seja: não moral (conhecimento do bem e do mal), mas tãosomente ontológica-existencial (apelo para o poder-ser originário, isto é: para a existência autêntica). A passagem a ser introduzida a seguir, extraída do Dicionário de Filosofia Ferrater Mora, alude ao sentido filosófico que Heidegger confere ao conceito estudado:

\begin{abstract}
Heidegger examinou o problema da consciência moral num sentido semelhante ao das outras manifestações da Existência, isto é, de um ponto de vista existencial. A consciência moral é um chamado, um 'invocar' que revela à existência sua vocação (Ruf), o que ela é em sua autenticidade. [...] Portanto, a consciência moral é, para Heidegger, um fenômeno existencial que parte da Existência e se dirige à Existência. Em suma, a Existência no fundo de seu estado de 'inospitalidade' no mundo é o verdadeiro 'vocador da vocação da consciência moral'. Por isso, a consciência moral revela-se como o chamado (ou 'vocação') do cuidado enquanto ser da Existência. Como a Existência, a consciência moral é sempre a minha; nenhum homem pode pedir auxílio a outro (ou a outros) para determinar qual o chamado ou vocação que lhe é próprio e que se manifesta pelo 'dizer silenciando' de sua consciência moral ${ }^{13}$.
\end{abstract}

Michael Inwood, em seu curto e didático texto denominado Heidegger, ressalta o sentido do vocábulo alemão que traduz os dois termos alemães Bewußtsein e Gewissen - por uma mesma palavra em português, limitando-se a

\footnotetext{
12 "Die existenzial-ontologischen Fundamente des Gewissens/ \$56 Der Rufcharakter des Gewissens/ \$7 Das Gewissen als Rufder Sorge".

Martin Heidegger, Op. Cit., 1976, p. 6, grifo nosso. Tradução nossa.

${ }^{13}$ Ferrater Mora, Dicionário de Filosofia - tomo I a IV, 2000, p. 556.
} 
diferenciá-los, respectivamente, por consciência e Consciência - o C maiúsculo assinala o uso especial que Heidegger faz da palavra Gewissen ${ }^{14}$. Ao destacar o sentido que o próprio Heidegger utiliza em Ser e Tempo, Inwood ressalta que "Nem todos têm uma consciência tradicional [Bewußtsein], mas todos têm uma Consciência [Gewissen $]^{15}$. Neste sentido, a

Consciência [Gewissen] não me diz que opções específicas escolher ou evitar, que ações empreender ou omitir, mas convoca-me a escolher, a agir, e a assumir a responsabilidade por essa escolha e essa ação. [...] Se ouço o chamado da Consciência, é porque quero ter uma Consciência. Todos têm uma Consciência, que os chama continuamente ${ }^{16}$.

Sendo assim, ao se fazer referência, no presente texto, ao termo consciência, tendo em vista o Heidegger de Ser e Tempo, não se trata de modo algum do sentido de reflexão de um eu sobre si mesmo [Bewußtsein] e sim de uma interpretação existencial da consciência enquanto Gewissen. Assim, nota-se que Heidegger "retira consciência e débito do seu contexto ético em função de um sentido mais fundamental e existencial"17. É precisamente por se debruçar sobre o sentido de Gewissen e interpretá-lo não moralmente, mas ontologicamente, que a contemporânea obra de Ser e Tempo se diferencia, por assim dizer, da tradição filosófica que tende a definir a consciência enquanto uma faculdade da alma, do entendimento; ou seja, tende a definir a consciência em termos de interioridade, em termos de reflexão de um eu sobre si mesmo (justamente o que indica a noção

\footnotetext{
${ }^{14}$ Michael Inwood, Heidegger, 2004, p. 97.

${ }^{15}$ Michael Inwood, Heidegger, 2004, p. 97.

${ }^{16}$ Ibidem, p. 97-98.

${ }^{17}$ Idem, Dicionário Heidegger, 2002, p. 22.
} 
de Bewußtsein). Martin Heidegger, em Ser e Tempo, assinala que é através da consciência - ao apelar e ao mesmo tempo compreender o clamor desse apelo [Ruf des Gewissens] - que o ser-aí [Dasein], pode ser a partir de si-mesmo, conforme explicitaremos a seguir com maior rigor.

Cabe destacarmos a consciência enquanto radicada fundamentalmente no ser-no-mundo [in-der-Welt-sein], pois, no limite, ela diz respeito ao movimento pelo qual o ser-aí, sendo-no-mundo, pode ser em sentido autêntico. É nesse sentido, também, que o Filósofo de Meßkirch distingue-se, no que tange à consciência, em relação à interpretação vulgar ${ }^{18}$ e distingue-se em relação a todas as ciências ônticas: ${ }^{19}$ a acepção de consciência não é afirmada em Ser e Tempo enquanto um fenômeno meramente histórico que, dessa forma, poderia advir ou não, antes, porém, é preciso levar em conta que a consciência é considerada pelo autor em questão como um existencial-ontológico, quer dizer, a exemplo da

\footnotetext{
${ }^{18} \mathrm{O}$ que Heidegger define por interpretação vulgar? A interpretação que esgota o objeto da consciência sob o ponto de vista da cotidianidade mediana: "na caracterização do fenômeno [da consciência] e de sua função, ela [interpretação vulgar] se atém à consciência impessoal determinando, impessoalmente, como ela a obedece ou não" (Martin Heidegger, Ser e Tempo parte II, 2005a, p. 77). Indo além, de acordo com o Dicionário Heidegger: "A interpretação ordinária difere da de Heidegger em quatro pontos: 1. A consciência possui uma função crítica. 2. Ela sempre nos fala de um feito definido que foi realizado ou desejado. A voz da consciência não tem uma relação tão radical com o ser de Dasein quanto Heidegger supõe. 4. A forma básica da consciência, rejeitada por Heidegger, é a má e a boa consciência, a que censura e a que adverte" (Idem).

${ }^{19} \mathrm{O}$ surgimento da noção de consciência na obra parece obedecer a um duplo movimento: por um lado, o autor destaca constantemente a consciência como um fenômeno existencial, que só se anuncia na existência e que vem a ser, por isto mesmo, passível apenas de surgir na análise ontológico-existencial; por outro lado, o autor preocupa-se deveras, ao longo da segunda seção do segundo capítulo, em diferenciar este seu conceito de consciência das problemáticas que são próprias da antropologia, psicologia, biologia ou das teorias baseadas na subjetividade (tais como a de Descartes e Kant). Neste sentido, Ernildo Stein destaca: “a questão existencial é introduzida em ST contra toda a tradição antropológica da época. O filósofo desenvolve sua analítica existencial numa rígida distinção da biologia, da etnologia e da psicologia" (Ernildo Stein, Seis estudos sobre 'Ser e Tempo', 2005, p. 12).
} 
compreensão [Verstehen], a consciência é um fenômeno a priori relativo à estrutura ontológica do ser-aí humano. Para Heidegger, a consciência se anuncia tão-somente com e na existência do ser-aí: "no contexto problemático desse tratado, a análise da consciência encontra-se unicamente a serviço da questão ontológica fundamental"20. Ou seja: o Heidegger de Ser e Tempo pretende situar a consciência enquanto radicada no ser-no-mundo, e será neste sentido que a consciência chegará a ser abordada como uma modalidade existencial [Existenzial], assim como todos os caracteres ontológicos enraizados no ser-nomundo, visto que "eles se determinam a partir da existencialidade"21. É sob esse aspecto que Ernildo Stein observa que: "Aqui se apresenta a questão paradigmática na qual é substituída a relação com o mundo através da consciência e da representação que sempre chegam tarde"22. Haja vista que o pensamento heideggeriano, nos anos 20, lutou veementemente contra o modelo da relação sujeito-objeto, evidencia-se que Ser e Tempo aborda o fenômeno da consciência, concebendo-a não mais como fundamento das teorias da subjetividade, antes, porém, procura situar a consciência enquanto radicada no ser-no-mundo. Neste sentido, vale, outra vez, o pertinente comentário de Stein: “A proposta de superação da relação sujeito-objeto, base das teorias da consciência, preparam, portanto, em Heidegger, a mudança do paradigma tradicional e a proposta de uma nova questão do método"23.

É sob essa perspectiva que Heidegger, ao trazer à liça sua acepção de consciência, não se coaduna com as teorias que em última instância se baseiam

\footnotetext{
${ }^{20}$ Martin Heidegger, Ser e Tempo - parte II, 2005a, p. 78.

${ }^{21}$ Martin Heidegger, Op. Cit., 1988, p. 80.

${ }^{22}$ Ernildo Stein, Seis estudos sobre 'Ser e tempo', 2005, p. 17.

${ }^{23}$ Ibidem, p. 32.
} 
na (tradicional) relação sujeito-objeto, baluarte esse que, diga-se de passagem, o autor visa a criticar e, através de Ser e Tempo, lançar fundamentos para sua superação. Como ser-no-mundo, o ser-aí não sai de uma consciência interna encapsulada e isolada, antes, porém, desde sempre esteve fora, isto é, sempre esteve no mundo, que por isso mesmo sempre foi de alguma forma descoberto pelo ente que nós mesmo somos: "O novo paradigma mostra o ser-no-mundo de onde apenas então emerge a consciência"24. Quer dizer, a consciência radica-se no ser-no-mundo, na medida em que implica no si-mesmo autêntico enquanto modo de ser-no-mundo. Assim, a consciência enquanto fenômeno constitutivo do ser-no-mundo situa-se em outro paradigma: "nem é mais a consciência que na tradição mentalista cartesiana espelha o mundo, nem é, na certeza deste espelhamento, o fundamento do conhecimento deste mundo"25. Posto isso, realizada brevemente a explicitação da consciência como fenômeno por excelência existencial - radicada na armação ontológica de ser-no-mundo -, passaremos, por conseguinte, à próxima exposição de nosso texto, na qual procuraremos trazer à tona um elemento considerado por Heidegger como de maior importância, quando o assunto é consciência, a saber: o apelo [Ruf $]^{26}$ ou o clamor da consciência.

Com efeito, "a análise mais profunda da consciência a desentranha como clamor [ou apelo]"27. Apelo em termos de suplicar com veemência, proclamar com ímpeto, chamar por algo imprescindível. O apelo da consciência proclama o

\footnotetext{
${ }^{24}$ Ibidem, p. 44.

${ }^{25}$ Ibidem, p. 27.

${ }^{26}$ Priorizaremos a palavra português mais corrente apelar, e suas variantes apelo e apelação, em relação ao termo alemão Ruf.

${ }^{27}$ Martin Heidegger, Ser e Tempo - parte II, 2005a, p. 54.
} 
ser-aí para o seu poder-ser-si-mesmo autêntico. Em que sentido, porém, Heidegger entende pela expressão poder-ser-si-mesmo autêntico? Tratar-se-á de um si-mesmo que examina sua vida interior? Tratar-se-á de um si-mesmo que medita acerca de seus estados de alma e das profundezas dessa? Manifestamente não. Antes de tudo, o si-mesmo sequer designa um sujeito: a tarefa (de tornar a ontologia fundamental evidente) exige, ou, nas palavras do próprio autor, “implica fixar as questões ontológicas possíveis referente ao si-mesmo na medida em que ele não é nem substância nem sujeito"28. Sob esse aspecto que o intérprete Jean-Paul Resweber assinala que “aos olhos de Heidegger, a subjetividade é o resultado desta tentativa pela qual o pensamento se exclui da esfera ontológica para pôr o ser diante dele como um objeto"29. Para Heidegger: "O simplesmente dar-se em conjunto do físico e do psíquico é, do ponto de vista ôntico e ontológico, inteiramente distinto do fenômeno do ser-no-mundo" ${ }^{30}$. Com isso, podemos de alguma forma contemplar outro questionamento aludido na introdução do presente texto, qual seja: o que Heidegger teria em vista com a afirmação de que o ser-aí tem consciência? Antes de tudo, faz-se necessário frisar que com essa ideia Heidegger não pretende afirmar que no Dasein há uma Selbstbewußtsein, que em português poderíamos traduzir por consciência de si próprio, autoconsciência ou mesmo consciência perceptiva.

Outro estudioso de Heidegger, Chen Yong, que escreveu uma tese sobre a diferença entre as noções de Consciência em Heidegger e em Descartes (Bewusstsein und Erschlossenheit - Untersuchung zu Descartes und Heidegger), defende que em Ser e Tempo não há em absoluto consciência de si

\footnotetext{
${ }^{28}$ Ibidem, p. 95.

${ }^{29}$ Jean-Paul Resweber, O Pensamento de Martin Heidegger, 1979, p. 83.

${ }^{30}$ Martin Heidegger, Ser e Tempo - parte I, 1988, p. 271, Grifo do autor.
} 
[Selbstbewußtsein], ao invés disso, haveria apenas Schuldbewusstesein, que poderíamos traduzir por consciência da culpa. Sendo assim, Heidegger pretende, com o conceito de consciência (a concepção de que o ser-aí tem consciência), abordar unicamente o si-mesmo enquanto modo de ser-no-mundo, e, mais precisamente, o modo de ser-no-mundo autêntico. Ou melhor: segundo a perspectiva heideggeriana, o ser-si-mesmo é um fenômeno existencial que, enquanto tal, pode estar em seus dois modos fundamentais de ser-no-mundo, quais sejam: autenticidade e inautenticidade (muito embora não podemos desconsiderar que Heidegger sugere em Ser e Tempo, algumas vezes, que o simesmo do ser-aí não está nem autêntico nem inautêntico, mas sim indiferente, Indifferenz); entretanto, embora o fenômeno existencial do si-mesmo possa ser modulado num sentido inautêntico (ainda que impessoal, o Dasein não perde a sua simesmidade), o ponto aqui, em específico, é que Heidegger, ao referir-se ao si-mesmo do ser-aí (ao versar sobre a consciência), tem em vista particularmente a autenticidade modal do si-mesmo. Quer dizer, o poder-ser-si-mesmo a que se refere Ser e Tempo limita-se ao ponto de vista tão-somente ontológico-existencial (podendo ser autêntico ou inautêntico), contudo, na medida em que o autor aborda a concepção de que o ser-aí tem consciência, com isso ele visa destacar o si-mesmo mais precisamente em seu modo de ser-no-mundo autêntico.

Assim sendo, investiguemos: o que no clamor da consciência constitui o objeto aclamado? O próprio ser-aí. E para que perspectiva se aclama, se apela? Para o poder-ser-si-mesmo autêntico. Vê-se, então, o trânsito ontológico pelo qual a apelação veemente do clamor é responsável: a passagem de uma situação na qual o ser-aí imerge no impessoal (ou seja, nessa condição em que ele procura fugir de si mesmo; não se colocando, portanto, diante de si mesmo), para uma 
outra condição em que o ser-aí coloca-se diante de si mesmo a partir do seu próprio ser.

Indo além, parece-nos decisivo articular a pergunta: quem clama, ou quem apela? A essa indagação se responde com a mesma precisão da questão de quem é proclamado no apelo, isto é: o ente que nós mesmos somos. Na consciência, o Dasein clama por si mesmo. A princípio, diminui-se o aparente caráter intrigante dessa resposta quando se pensa que, do ponto de vista ontológico, o clamor não pode porvir de um outro que está-no-mundo mas apenas de mim: "O clamor provém de mim e, no entanto, por sobre mim"31. Por isso, notemos que: o clamor nasce em mim, provindo de mim e por sobre mim. Ademais, parece-nos necessário ir mais adiante na resposta à pergunta quem clama. Em última instância, trata-se do Dasein em sua estranheza. É com a noção de estranheza marcada a falta de sentido no mundo que se desentranha na disposição da angústia, que coloca o ser-no-mundo diante do nada do mundo com o qual ele se angustia. “O clamor coloca o Dasein diante de seu poder-ser e isso enquanto clamor proveniente da estranheza"32. Portanto, quem clama? O Dasein em sua estranheza, o ser-nomundo enquanto um não-se-sentir-em-casa, em suma: "o si-mesmo singularizado na estranheza de si e lançado no nada"33.

Mas o que um dos principais nomes da filosofia contemporânea - Martin Heidegger - tem em vista, afinal, com o conceito de estranheza, em alemão Unheimlichkeit? (José Gaos, no seu livro Introducción a El Ser y El Tiempo de Martin Heidegger, traduz o vocábulo alemão Unheimlichkeit por inhospitalidade ${ }^{34}$ ); qual a

\footnotetext{
${ }^{31}$ Idem, Op. Cit., 2005a, p. 61, grifo do autor.

${ }^{32}$ Ibidem, p. 67, Grifo do autor.

${ }^{33}$ Ibidem, p. 63, Grifo do autor.

${ }^{34}$ José Gaos, Introducción a El Ser y El Tiempo de Martin Heidegger, 1971, p. 69.
} 
sua relação com a angústia [Angst] ${ }^{35}$ ? E por que quem clama é o ente existente na sua estranheza, na sua inospitalidade?

Angústia, para Heidegger, deve ser entendida, antes de tudo, como uma tonalidade afetiva, em alemão Stimmung, cujas traduções podem ser temperamento ou disposição afetiva. Com isso, porém, o Filósofo não se refere a um sentimento interior, a um estado psicológico, antes, porém, o Stimmung diz respeito ao próprio modo de ser existencial do ser-aí. No $§ 29$ de Ser e Tempo, de 1927, o próprio autor reforça que, ao se utilizar do termo Stimmung, com isso ele visa um sentido ontológico, e não ôntico; sendo assim, a tonalidade afetiva em sentido heideggeriano (ontologia) é anterior a toda psicologia dos temperamentos (ôntico). No livro O que é metafísica?, de 1929, ele assinala: “o que assim chamamos sentimentos não é nem um fenômeno secundário fugidio de nosso comportamento pensante e volitivo, nem um simples impulso causador de tal fenômeno" ${ }^{\prime 36}$. Sendo assim, quando se fala de tonalidade afetiva [Stimmung], em Heidegger, trata-se de um modo de ser, e, mais do que isso, um modo de ser da existência do ser-aí em que algo lhe é revelado, ou, no caso da tonalidade afetiva fundamental - a angústia -, o próprio nada lhe é revelado.

A angústia é o fenômeno buscado na própria estrutura ontológica do ente cuja essência coincide com a existência. Primeiramente, angústia não se angustia, de modo algum, com determinado ente que está dentro do mundo. Na verdade, "o com quê da angústia é inteiramente indeterminado" ${ }^{37}$. Em vista disso, Stegmüller corrobora:

\footnotetext{
${ }^{35}$ Sugestões de traduções para o português: angústia, ansiedade e desconforto (Michael Inwood, Dicionário Heidegger, 2002, p. 7).

${ }^{36}$ Martin Heidegger, O que é Metafísica?, 2008, p. 120.

${ }^{37}$ Idem, Ser e Tempo - parte I, 1988, p. 250.
} 
Ao contrário do medo, que se dirige sempre para alguma coisa determinada [...], falta na angústia um objeto determinado, algo com que se fique angustiado. Ela é sem fundamento, mas, ao mesmo tempo, de uma totalidade absoluta ${ }^{38}$.

A possibilidade da angústia, portanto, não está relacionada com a possibilidade de ameaça ou dano de determinado ente que vem ao encontro dentro do mundo. A angústia não sabe o que é aquilo com que se angustia, visto que não há algo propriamente dito para o qual se angustia. Neste sentido, se a angústia não traz a ameaça de um ente definido, ela carece, então, de conjuntura [Bewandtnis], quer dizer: a angústia não se angustia com algo específico e por isso mesmo não estabelece conjuntura - somente entes sem mundo possuem conjuntura. Justamente porque com ela o mundo torna-se insignificante, perde sentido (pouco importa esse ou aquele ente). Ou seja, ela se angustia com o mundo como tal (e não determinada região), o que nos permite concluir, por assim dizer, que aquilo com que ela se angustia é o nada (a nadificação de um mundo insignificante). "Fenomenalmente, a impertinência do nada e do em parte alguma intramundana significa que a angústia se angustia com o mundo como tal" $^{\prime 39}$. A total insignificância que se anuncia no nada revela que um ente desprovido da estrutura do ser-no-mundo, em si mesmo, tem pouca relevância em termos de apresentar alguma ameaça para angústia. Por isso o angustiar-se abre, de modo originário, o mundo como mundo, pois abre-o enquanto nadificação da sua insignificância - a angústia despe o mundo da sua totalidade de envolvimento significativo. Seguindo o raciocínio, qual é a sua relação com a estranheza? Visto que a angústia descobre o ser-aí nu e cru e seu mundo

\footnotetext{
${ }^{38}$ Wolfgang Stegmüller, A filosofia contemporânea: introdução crítica, 1977, p. 130.

${ }^{39}$ Martin Heidegger, Ser e Tempo - parte I, 1988, p. 250, Grifo do autor.
} 
insignificante e indiferente, podemos concluir, com Heidegger, que a angústia faz com que achemos tudo estranho (sem lar).

Cingido pela angústia, o ser-aí sente-se fora de casa como ser-no-mundo (estranho indica neste caso não se sentir em casa). Daí o porquê que é o ser-aí na sua estranheza quem clama no apelo da consciência: o ser-aí imerso na impessoalidade - justamente o que a consciência quer resgatar - sente-se enraizado, acolhido, sente-se em casa; por outro lado, porém, uma vez o ser-aí angustiado, ele implica em desenraizamento, desterro, desabrigo. Essa é a característica em que se encontra o ente existente uma vez na angústia: o de estranheza. $O$ apelo provém da estranheza proporcionada pela angústia, justamente porque a angústia realiza a abertura originária e primária do mundo como mundo e do ser-no-mundo como ser-no-mundo, ou seja: já não é mais possível ao ente existente afundar-se na decadência, em alemão Verfallen. "A angústia retira, pois, do Dasein a possibilidade de, na decadência, compreender a si mesmo a partir do 'mundo' e na interpretação pública" ${ }^{40}$. O apelo da consciência provém do ser-aí angustiado, para Heidegger, justamente porque a disposição da angústia retira a possiblidade do ser-aí permanecer encoberto para si mesmo uma vez na publicidade [Öffentlichkeit] do impessoal. Posto isso, passaremos ao próximo item de nosso texto, no qual procuraremos destacar, a partir do tratado de 1927, a consciência como um modo de discurso.

De acordo com o filósofo alemão: “Apreendemos o clamor [ou apelo] como modo do discurso"41. É interessante notar que, quando Heidegger versa sobre o discurso enquanto estrutura originária fundante, no limite ele está (re)

\footnotetext{
${ }^{40}$ Ibidem, p. 251.

${ }^{41}$ Idem, Op. Cit., 2005a, p. 56.
} 
interpretando o entendimento grego de lógos. Os gregos, especialmente Aristóteles, tiveram olhos para ver a essência do homem determinada pelo lógos que, posteriormente, passou a ser interpretada no sentido de animal rationale. Para Martin Heidegger ${ }^{42}$, tal interpretação não é categórica e absolutamente falsa, mas o problema é que essa perspectiva assim disposta acaba por velar e encobrir um solo mais fundamental e originário o qual deu origem à definição grega do lógos. A essência humana reside no lógos na medida em que o homem se mostra um ente que é no discurso (os gregos não tinham uma palavra propriamente para designar linguagem, pois entendiam esse fenômeno principalmente enquanto discurso). Isso não significa que o homem é o único ente que tem a possibilidade de articulação sonora, como se essa fosse um apanágio de distinção ou superioridade humana, e sim que o homem, no discurso, abre-se no modo de des-coberta do mundo e do próprio ser-aí - no discurso, o homem se realiza. Assim, situando o discurso em seu devido lugar ontológico, o autor toma o fenômeno dentro da constituição ontológica do único ente existente: discurso é articulado ao ser-aí no sentido de familiaridade originária com o mundo (condição pré-temática). Neste sentido, discurso está como determinação ontológica exclusiva do ser-aí - aliás, do ponto de vista ontológico, somente o ser-aí é no discurso.

No entanto, quando o filósofo alemão destaca que a consciência é um modo de discurso, com isso ele não quer dizer que a consciência tem algo a dizer. Não se trata, neste caso, de discurso verbalizado. Uma vez que o apelo é apreendido como modo de discurso, o que a consciência clama para o aclamado? Isto é, o que se discorre nesse discurso? "Em sentido rigoroso, nada. O clamor não

${ }^{42}$ Idem, Op. Cit., 1988, p. 224. 
exprime nada, não fornece nenhuma informação sobre acontecimentos do mundo, nada tem para contar"43. O apelo (o clamor) dispensa qualquer verbalização e não necessita da palavra para se manifestar.

Assim sendo, o apelo da consciência não pretende estabelecer com o seu objeto de apelação uma conversa negociadora, uma negociação, mas, isto sim, o apelo é uma veemente pro-clamação no sentido de convocar o ser-aí para adiante das suas possibilidades mais próprias.

A falta de verbalização do que, no clamor, se clama não remete o fenômeno à indeterminação de uma voz misteriosa, mas mostra apenas que a compreensão não deve se apoiar na expectativa de uma comunicação ou de algo parecido ${ }^{44}$.

Com isso, concluímos: o discurso da consciência apenas se dá em silêncio. Para Heidegger, "A escuta e o silêncio pertencem à linguagem discursiva como possibilidades intrínsecas" ${ }^{45}$. Sob esse aspecto, vale ressaltarmos um excerto de Stephen Mulhall:

Como o termo Ruf (apelar, conclamar ou chamar) sugere, Heidegger pensa na voz da consciência como um modo de discurso - uma forma de comunicação que atenta para interromper o falatório do 'eles mesmos' em que o Dasein está normalmente, para obter uma resposta no Dasein que se opõe a todo aspecto desse discurso inautêntico ${ }^{46}$.

\footnotetext{
${ }^{43}$ Idem, Op. Cit., 2005a, p. 59.

${ }^{44}$ Martin Heidegger, Ser e Tempo - parte II, 2005a, p. 59.

${ }^{45}$ Idem, Op. Cit., 1988, p. 220.

46 "As the term 'call' suggests, Heidegger thinks of the voice of conscience as a mode of discourse - a form of communication that attempts to disrupt the idle talk of the they-self to which Dasein is ordinarily attuned, to elicit a responsiveness in Dasein that opposes every aspect of that inauthentic discourse."

Stephen Mulhall, Heidegger and Being and Time, 2005, p. 138. Tradução nossa.
} 
Nota-se, assim, que o discurso da consciência, diferentemente da conversa fiada do falatório [Gerede], sempre e apenas se dá em silêncio. E isso porque o que está em jogo é o movimento convocatório para adiante - o ser-aí é convocado à silenciosidade de si-mesmo:

Entendido como discurso originário do Dasein, o clamor exclui todo e qualquer contradiscurso, algo no sentido de uma discussão negociadora do que diz a consciência. [...] A consciência só clama em silêncio, ou seja, o clamor provém da mudez da estranheza e reclama o Dasein conclamado para aquietar-se na quietude de si mesma ${ }^{47}$.

Daí a articulação entre a falta de verbalização que jaz no apelo (que jaz no clamor) enquanto discurso e o agente que clama nessa apelação: o ser-aí na sua estranheza, o ser-no-mundo enquanto um não-se-sentir-em-casa, clama em silêncio. "E isso somente porque o clamor não aclama para o falatório público do impessoal mas sim para dele sair e passar para a silenciosidade do poder-ser

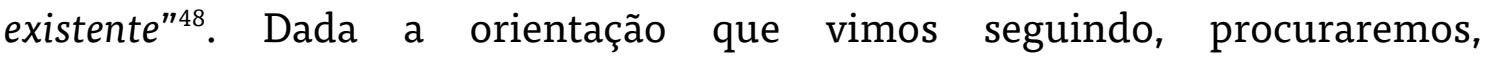
imediatamente, avançar em direção às conclusões finais do presente artigo; para tanto, urge agora trazermos à tona uma marcante característica da consciência, segundo o filósofo alemão, a saber: o caráter de violência.

Seguindo a reconstrução temática da consciência em Ser e Tempo, tal como ela consta na segunda seção dessa obra, apresentaremos, neste item, uma aparente aporia com a qual a noção heideggeriana de consciência se depara. Assim, evidenciou-se, antes, que o trânsito ontológico pelo qual a apelação do clamor é responsável diz respeito, pois, à passagem de uma situação na qual o ser-

\footnotetext{
${ }^{47}$ Martin Heidegger, Ser e Tempo - parte II, 2005a, p. 85-86.

${ }^{48}$ Ibidem, p. 63, grifo do autor.
} 
aí imerge no impessoal, para uma outra em que ele se coloca diante de si mesmo a partir do seu próprio ser. Indaga-se, porém, o pensador alemão: se a perspectiva para qual a consciência clama é o poder-ser-si-mesmo em sentido autêntico, como, então, ela pode concretamente se efetivar se a tendência do ser-aí consiste justamente em se encobrir e fugir de si mesmo ${ }^{49}$ Segundo Heidegger, é o próprio ente definido essencialmente pela existência que oferece constantemente a si mesmo a tentação de perder a si mesmo; ora, como então o apelo da consciência pode se efetivar? Tendo em vista que o ser-aí mantém-se preso na decadência [Verfallen] devido a sua própria constituição ontológica (de tendência) tentadora, como superar esta (aparente) aporia para impedir o fracasso da noção existencial de consciência? "O filósofo luta, portanto, contra as consequências de decaída que é uma das estruturas do estar-aí" ${ }^{50}$.

Não obstante, a consciência, enquanto fenômeno existencial, supera a tendência do ser-aí do seu encobrimento precisamente através de um caráter de violência. Tal caráter é evidenciado por Heidegger quando o autor confere ${ }^{51}$ um sentido de sobressalto brusco, abrupto, súbito. O ser-no-mundo é levado ao simesmo autêntico, ao ser abruptamente, forçosamente (violência), privado do refúgio e do esconderijo que é a impessoalidade: "Porque apenas o si-mesmo do próprio-impessoal é aclamado e forçado a ouvir, o impessoal sucumbe em si mesmo"52. $\mathrm{O}$ apelo insere um momento de impacto brusco na medida em que o

\footnotetext{
${ }^{49}$ De acordo com o autor (Martin Heidegger, Ser e Tempo - parte I, 1988, p. 220), é o próprio ser-aí quem oferece constantemente a si mesmo a tentação de perder a si mesmo, ou seja, pertence ao próprio ente que nós mesmos somos a tendência de se encobrir e fugir de si mesmo. O ser-aí humano mantém-se preso na decadência devido a sua própria constituição ontológica (de tendência) tentadora.

${ }^{50}$ Ernildo Stein, Seis estudos sobre 'Ser e tempo', 2005, p. 62.

${ }^{51}$ Martin Heidegger, Ser e Tempo - parte II, 2005a, p. 57.

${ }^{52}$ Ibidem, p. 58, grifo nosso.
} 
ser-aí é convocado a deixar de se perder no domínio da impessoalidade. Justamente nesta perspectiva que, à luz do apelo (ou clamor), se dá um momento de impacto brusco, pois, uma vez que a apelação (ou aclamação) "não toma o menor conhecimento de tudo isso" ${ }^{23}$, isto é, não hesita diante do refúgio e esconderijo que em verdade é a impessoalidade, o ser-aí é convocado a deixar de se perder no domínio da impessoalidade. Quer dizer, o sobressalto brusco inserido pelo apelo está no sentido de resgatar o ser-aí contra a sua tendência de encobrimento, e convocá-lo para assumir o seu si-mesmo. Dito de maneira mais literal: “o clamor ultrapassa o que o Dasein, de início e na maior parte das vezes, compreende a seu respeito, a partir da interpretação das ocupações" ${ }^{54}$. Assim, visto que o apelo (o clamor) constitui “um motivo de ele [ser-aí] prestar atenção a si mesmo"55, o domínio da publicidade [Öffentlichkeit] do impessoal - no qual o ser do Dasein é tomado pelos outros - sucumbe diante do si-mesmo. E porque sucumbe? Precisamente porque, na apelação do clamor, a impessoalidade é empurrada para sua devida falta de sentido: "Justamente no ultrapassar, o clamor empurra o impessoal, absorvido nas considerações públicas, para a insignificância" 56 .

Indo além, nota-se que, de acordo com o tratado filosófico de Ser e Tempo, a consciência dá algo - ela abre algo - para se compreender. Neste sentido, a interpretação da consciência haverá, segundo Heidegger, “de ampliar a análise anterior da abertura do Da do Dasein" ${ }^{57}$. O filósofo alemão assinala que o que se

\footnotetext{
${ }^{53}$ Ibidem, p. 58.

${ }^{54}$ Ibidem, p. 60.

${ }^{55}$ Ibidem, p. 58.

${ }^{56}$ Ibidem, p. 58.

${ }^{57}$ Ibidem, p. 55.
} 
constitui essencialmente pelo ser-no-mundo é sempre o Da do Dasein (o aí do seraí), que no limite indica uma abertura [Erschlossenheit] existencial desse ente que nós mesmos somos. Com isso, o autor de Ser e Tempo pretende em última instância demonstrar que o $\mathrm{Da}$ revela, por assim dizer, o caráter de nãofechamento existencial do Dasein. “A expressão 'Da' refere-se a essa abertura essencial. Através dela, esse ente [ser-aí] está junto ao pre-sente do mundo e se faz pre-sença para si mesmo"58. E mais, o caráter de não-fechamento existencial indica, principalmente, que o Dasein é, enquanto ser-aí, essencialmente aberto. Portanto, ainda que pertença ao próprio ser-no-mundo a tendência de se encobrir e fugir de si mesmo, a consciência dá algo a compreender justamente para o nãofechamento existencial do Dasein. O apelo alcança o ser-no-mundo justamente no movimento de sempre já se ter aberto, de tal modo que ele já sempre se compreendeu. O que a consciência abre, abre para abertura [Erschlossenheit] existencial do ser-no-mundo, a despeito da sua tendência de encobrimento.

Mas, pergunta-se: afinal, o que a consciência abre? Segundo Martin Heidegger, abre a possibilidade do ser-aí interromper a perdição em que ele se encontra no impessoal. Clamando, o que a consciência abre para se compreender é a possibilidade de o ser-aí retirar-se da pulverização da publicidade do impessoal. Com efeito, a este raciocínio podem-se somar duas observações: por um lado, o que a consciência abre é, não obstante, unívoco e preciso, ainda que possa ser recepcionada por diversas interpretações, de acordo com as possibilidades de compreensão de cada ser-aí singular; por outro lado, o apelo não dá a compreender - como se poderia crer numa leitura sumária de Ser e Tempo - a referência de um poder-ser ideal o qual deve ser universalmente perseguido

${ }^{58}$ Martin Heidegger, Op. Cit., 1988, p. 186. 
pelos vários seres-aí; assim, diferentemente das vias interpretativas acerca da consciência que se baseiam numa subjetividade, o apelo da consciência, em Heidegger, não visa um estado ideal em que um agente deve alcançar, antes, porém, o que a consciência abre é o poder-ser como a singularidade de cada serno-mundo. O ser do ser-aí é sempre meu, daí o porquê do Dasein nunca poder ser ontologicamente apreendido como um caso referencial a ser copiado: "A interpelação do Dasein deve dizer sempre também o pronome pessoal, devido a seu caráter de ser sempre meu: 'eu sou', 'tu és""59. Conclui-se, então, que o que a consciência abre é unicamente o poder-ser de acordo com a singularidade de cada ente existente.

\section{Algumas considerações finais}

Heidegger trouxe à tona o problema da consciência a partir de sua raiz terminológica a qual implica em consciência moral, Gewissen. Em Ser e Tempo, porém, o Filósofo alemão vale-se do termo Gewissen e interpreta-o sob uma nova perspectiva, qual seja: não moral (conhecimento do bem e do mal), mas tãosomente ontológica-existencial. É precisamente por se debruçar sobre o sentido de Gewissen e interpretá-lo não moralmente, mas ontologicamente, que a contemporânea obra de Ser e Tempo se diferencia, por assim dizer, da tradição filosófica que tende a definir a consciência enquanto uma faculdade da alma, que tende a definir a consciência em termos de interioridade, em termos de reflexão de um eu sobre si mesmo (justamente o que indica a noção de Bewußtsein). Ou seja, o autor de Ser e Tempo examinou o problema da consciência tal qual inquiriu

\footnotetext{
${ }^{59}$ Ibidem, p. 78, Grifo do autor.
} 
as demais manifestações da Existência, a saber: sob um ponto de vista ontológicoexistencial. É sob essa perspectiva, também, que o Filósofo de Meßkirch distingue-se, no que tange à consciência: a acepção de consciência não é afirmada em Ser e Tempo enquanto um fenômeno meramente histórico que, dessa forma, poderia advir ou não; antes, porém, é preciso entendermos que a consciência é considerada pelo autor em questão como um existencial-ontológico, que, a exemplo da compreensão [Verstehen], a consciência está como um fenômeno $a$ priori relativo à estrutura ontológica do ser-aí humano.

O apelo da consciência, para Heidegger, manifesta-se através de uma voz que não tem o que dizer, antes, porém, permanece em silêncio com o propósito existencial de recuperar o ente que nós mesmos somos para o modo autêntico de ser-no-mundo. Em sendo assim, o que Heidegger pretende, com a ideia de que o ser-aí tem consciência, é abordar unicamente o si-mesmo enquanto modo de serno-mundo, e, mais precisamente, o modo de ser-no-mundo autêntico, e não que o ser-aí tem em absoluto uma consciência de si, autoconsciência [Selbstbewußtsein]. O si-mesmo a que se refere Ser e Tempo limita-se ao ponto de vista ontológicoexistencial e, enquanto tal, diz respeito especificamente e tão somente ao modo autêntico de ser-no-mundo.

No que diz respeito à voz da consciência, através da qual o apelo se manifesta, trata-se de uma voz que nasce do ser-aí, e, ao mesmo tempo, sobre o ser-aí - ressalta-se: o ser-aí, porém, atingido pela angústia. Sendo assim, a voz da consciência provém do e sobre o ser-aí angustiado que, através de um discurso silencioso, apela para o seu próprio poder-ser, e por isso mesmo o fenômeno em questão é abordado na obra de Ser e Tempo como originário. 


\section{Referências}

ABBAGNANO, Nicola. Dicionário de filosofia. 3. ed. Trad. Alfredo Bosi. São Paulo: Martins Fontes, 1998.

BLACKBURN, Simon. Dicionário Oxford de filosofia. Trad. Desidério Murcho. Rio de Janeiro: J. Zahar, 1997.

CRITCHLEY, Simon; SCÜRMANN, Reiner. On Heidegger's Being and Time. New York: Routledge, 2008.

GAOS, José. Introducción a El Ser y El Tiempo de Martin Heidegger. 2. ed. México: Fondo de Cultura Económica, 1971.

HEIDEGGER, Martin. Sein und Zeit. Frankfurt am Main: Vittorio Klostermann, 1976.

HEIDEGGER, Martin. Ser e Tempo - parte I. 2. ed. Trad. Márcia de Sá Cavalcante. Petrópolis: Vozes, 1988.

HEIDEGGER, Martin. Ser e Tempo - parte II. 12. ed. Trad. Marcia de Sá

Cavalcante. Petrópolis: Vozes, 2005a.

HEIDEGGER, Martin. Ser y Tiempo. Trad. Jorge Eduardo Rivera. Santiago do Chile: Editorial Universitária, 2005b.

HEIDEGGER, Martin. O que é Metafísica?. Trad. Enio Paulo e Ernildo Stein. Petrópolis: Vozes, 2008.

HEIDEGGER, Martin. Ser e Tempo [bilíngue]. Trad. Fausto Castilho. Campinas: Unicamp; Petrópolis: Vozes, 2012.

INWOOD, Michael. Dicionário Heidegger. Trad. Luísa Buarque de Holanda. Rio de Janeiro: J. Zahar, 2002. 
INWOOD, Michael. Heidegger. Trad. Adail Ubirajara Sobral. São Paulo: Loyola, 2004.

MANZI, Ronaldo. O que seria a consciência na fenomenologia heideggeriana? Griot: Revista de Filosofia, Amargosa, v. 13, n. 1, p. 183-199, jun. 2016.

MERTENS-KAHLMEYER, Roberto. Resenha: Heidegger, Martin. Ser e tempo. Trad. de Fausto Castilho. Editora da Unicamp; Vozes, 2012. 1200p. Revista Húmus, Maranhão, n. 8, p. 103-104, ago. 2013.

MORA, Ferrater. Dicionário de Filosofia - tomo I a IV. Trad. Maria Gonçalves, Adail Sobral, Marcos Bagno e Nicolás Campanário. São Paulo: Loyola, 2000. MULHALL, Stephen. Heidegger and Being and Time. 2. ed. Oxford: Routledge, 2005.

RESWEBER, Jean-Paul. O Pensamento de Martin Heidegger. Trad. João Agostinho A. Santos. Coimbra: Livraria Almedina, 1979.

SAFRANSKI, Rüdiger. Heidegger - um mestre da Alemanha entre o bem e o mal. Trad. Lya Luft. São Paulo: Geração Editorial, 2000.

STEGMÜLLER, Wolfgang. A filosofia contemporânea: introdução crítica. São Paulo: EPU, 1977.

STEIN, Ernildo. Seis estudos sobre 'Ser e tempo'. 3. ed. Petrópolis: Vozes, 2005.

TUGENDHAT, Ernst. Heideggers Idee von Wahrheit. In: PÖGGELER, Otto (Hg.). Heidegger: Perspektiven zur Deutung seines Werks. Köln: Kiepenheurer \& Witsch, 1969. p. 286-297.

TUGENDHAT, Ernst. Selbstbewusstsein und Selbstbestimmung:

Sprachanalytische Interpretationen. Frankfurt: Suhrkamp, 1981. 
YONG, Chen. Bewusstsein und Erschlossenheit - Untersuchung zu Descartes und Heidegger. 2013. Disponível em: https://doi.org/10.11588/heidok.00015313. Acesso em 31 jan. 2020.

\section{Referência para citação deste artigo}

ARAÚJO, Fabíola Menezes; ALMEIDA, Rafael Ribeiro. Sobre o conceito de consciência em Heidegger. Revista PHILIA | Filosofia, Literatura \& Arte, Porto Alegre, volume 2, número 1, p. 232 - 259, junho de 2020. 